in India"; Mr. A. J. Gibson, "The Story of Lac" ; Dewan Bahadur S. E. Runganadhan, "The Work of Indian Universities". Paper read before the Dominions and Colonies Section: Dr. Maurice Ashby, "British Empire Drug Production". Endowed Lecture : The Right Hon. Viscount Bennett, "Empire Relations".

\section{American Chemical Society Prize in Pure Chemistry}

The American Chemical Society Prize in pure chemistry of 1,000 dollars has been awarded for 1942 to Dr. John Lawrence Oncley, associate in physical chemistry at the Harvard Medical School and instructor in chemistry at the Massachusetts Institute of Technology. This Prize is given annually for "outstanding research in pure chemistry by a man or woman less than thirty-six years old'. Dr. Oncley has made important contributions to protein chemistry and he has investigated the dielectric properties of gases, insulating oils, resins, rubbers and proteins, developing radio-frequency bridge methods suitable for precise dielectric constant determinations with proteins. With the aid of these methods he completed the first satisfactory study of the dielectric dispersion behaviour of water-soluble proteins. This work constitutes one of the significant contributions of recent years to protein chemistry and has led to further studies on the molecular size and shape of protein molecules.

\section{Award of the Dr. W. S. Bruce Memorial Prize}

THE joint committee consisting of representatives from the Royal Society of Edinburgh, the Royal Physical Society and the Roy'al Scottish Geographical Society has awarded the Bruce Prize to Dr. G. C. L. Bertram for valuable biological work in the Arctic and Antarctic during 1932-37; and especially for his work as biologist with the Graham Land Expedition during 1934-37, when he took part in the important sledging journey which discovered King George VI Sound. His particular work was on seals, and he has written an important memoir entitled "The Biology of the Weddell and Crabeater Seels", published by the British Museum (Natural History) in September 1940 in the British Graham Land Expedition Reports. In addition, Dr. Bertram is the author of a more popular book on the technique of polar travel entitled "Arctic and Antarctie".

\section{Bicentenary of Abraham Sharp}

ON July 15, 1742, the mathematician and astronomer Abraham Sharp died at his birth-place, Little Horton, near Bradford, Yorks., at the age of ninety-one, having in various ways furthered the interests of British astronomy. After serving an apprenticeship to a merchant at Manchester, he opened a school at Liverpool, where Flamsteed met him. The meeting led to Sharp joining Flamsteed in the newly erected Royal Observatory at Greenwich where he worked from 1676 until 1690 . In 1688 Sharp was given the task of constructing a mural quadrant of $79 \mathrm{in}$. radius, and this proved to be the most satisfactory instrument Flamsteed possessed. With his other instruments it was removed from Greenwich by his executors after Flamsteed's death, but some eighty years ago parts of a similar instrument by Sharp were given to the Observatory by the Rev. N. S. Heineken. On leaving Greenwich, Sharp settled at Little Horton, calculating, making instruments and corresponding with scientific men.
He supplied Flamsteed with observations, and with Crosthwait, Flamsteed's last assistant, he had a share in the publication of the "Historia Coelestis Britannica", which appeared in 1725, six years after Flamsteed died. In a letter written in January 1722 , Crosthwait wrote to his collaborator that "the memory of the ingenuous and disinterested Mr. Sharp will always, by me, be had in the greatest esteem, next to that of my deceased and good friend $\mathrm{Mr}$. Flamsteed"

\section{Dr. Charles B. Dudley, 1842-1909}

EAcH year, the American Society for Testing Materials awards a medal for some outstanding contribution to research in engineering materials, and to commemorate the eminent services of the Society's first president, Dr. Charles B. Dudley, who was born on July 14, 1842. Brought up in Chenango County, New York, Dudley at the age of twenty enlisted in the 114th New York Volunteers, fought in a number of battles during the Civil War, and was severely worunded. In 1865 he was free to resume his interrupted studies, and during the next nine years worked at the Oxford Academy, Chenango Co., Yale College and the Sheffield Scientific School of Yale College. Part of his time was spent on newspaper work to provide him with necessary funds. On leaving Yale in 1874 with the degree of Ph.D, he devoted a short time to teaching chemistry and physics at the University of Pennsylvania and at a Military Academy at Poughkeepsie; and then in 1875 became chemist to the Pennsylvania Railroad Company, with headquarters at Altoona, Pa., where he installed labora. tories. Much of his work was of a pioneering char. acter and it gradually spread to investigations on all the materials used in the building and working of a railway, from the laying of the track to the ventilation of carriages. Especially important were his researches on rails. Besides being the founderpresident of the American Society for Testing Materials, he served as president of the American Chemical Society and at the Copenhagen Congress of the International Association for Testing Materials held in 1909 he was chosen president for the ensuing three years. Soon after his election, however, he died unexpectedly on December 21, at the age of sixty-seven.

\section{0-kw. Short-Wave Radio Transmitter}

AN article by F. D. Webster and R. E. Downing (Elec. Comm., 20, No. 3, 1942) describes a new equipment built for All America Cables and Radio Inc. for use in the expansion of its international service at Lima, Peru. The equipment is capable of operating on any frequency between $5 \cdot 7 \mathrm{mc}$. and 22 mc., with crystal control or with self-excitation, for carrier wave or modulated carrier wave telegraphy or by means of a separate modulator for telephone or broadcast, to deliver $1 \mathrm{kw}$. or $30 \mathrm{kw}$. of radio frequency power on telegraphy or $9 \mathrm{kw}$. on telephony or broadcast, and of delivering its rated output at any frequency between 5.7 mc. and 22 me. into a balanced transmission line of $600 \mathrm{ohms}$ surge impedance with any standing wave ratio up to 2 to 1 .

Flexibility is achieved by constructing the equipment in four mechanically separate units and by the provision of controls which permit rapid and convenient transfer to any type of operation. The four units comprise a radio frequency driver, a power am. 
plifier, a 3,000-volt rectifier and a. 10,000-volt rectifier. For telephone operation two more units are required, namely, a speech amplifier and a modulator. Voltage breakdown, which is an ever-present hazard due to the high voltages produced in radio equipment of this power, is minimized by adequately spacing and insulating all components, by avoiding sharp edges on metal parts, and by installing corona shields and horn gaps where applicable. Excessive temperatures are avoided by employing adequate current-carrying capacity in all conductors, ample radiating surfaces, water cooling, and forced air circulation by means of blowers.

Recent developments incorporated in this equipment include electronic keying with weight control, modulated carrier wave telegraphy by phase modulation, special type balancing network, multistrand filament tube, vacuum condensers. The article gives, at some length, details of the electrical design and the mechanical construction of the general assembly of the equipment and of the component parts which come broadly under the headings of controls, personnel protection, radio frequency driver unit, power amplifier unit, 3,000-volt rectifier unit and 10,000-volt rectifier unit. A table of specifications summarizes the more detailed equipment description.

\section{Optics Applied to Engineering}

A LeCture entitled "Optics Applied to Engineering" was delivered by Mr. K. J. Habell at a meeting of the Leicester Branch of the Association of Scientific Workers held on June 2 at the College of Technology, Leicester. Mr. Habell described the principles of several types of optical instruments now in increasing use in engineering workshops, and much interest was shown in those of the more difficult types of profile projection. The application of telecentric systems for the avoidance of magnification errors due to incorrect focusing and to ensure the imagery of the correct profile was very well illustrated by diagram. matic and experimental slides showing the images of a circular hole produced by convergent, divergent and collimated beams of light. Other instruments described included the tool-room microscope for the examination of form tools and screw-thread forms, and alignment telescopes for measuring the alignment and relative tilt of closely or widely separated bearings and jigs. Details were given of auto-collimating telescopes for high precision work in angular measurement. The importance to the war effort of instru ments of the types described was emphasized. A selection of the instruments was on view, and was demonstrated after the meeting.

\section{Chemical Engineering at Leeds}

The Department of Coal Gas and Fuel Industries (with Metallurgy) of the University of Leeds was established in 1906 to provide degree courses in fuel and metallurgy. In 1910 a fund was raised by the gas industry in order to perpetuate the memory of Sir George Livesey, the distinguished gas engineer, and this was allocated to endow the chair of the Department now known as the Livesey professorship. A degree course in gas engineering was instituted at that time. Since then the Livesey Advisory Committee, which is composed of representatives of the Institution of Gas Engineers, of the Society of British Gas Industries, and of the University, has had under consideration the need for extending the courses in order to keep pace with the growth of knowledge and the increasing demands of industry. In particular, for those passing into the constructional side of the gas industry and into the larger undertakings as well as to the staffs of chemical plant manufacturers generally, a broader training is necessary. On this account the Committee recently recommended the establishment of an alternative four-year course in chemical engineering, which has now been approved by the University; the new course will begin with the autumn term.

\section{Domestic Electricity Supply}

AN optional-control system of domestic electricity supply is described by P. Schiller (J. Inst. Elec. Eng., 89, Pt. 2, No. 9 ; June, 1942), which is designed to meet the objection often raised to domestic load control of any kind, in that it involves encroachment on the consumer's liberty to use his supply as he wishes. It is suggested in the paper that the consumer be given the opportunity at any moment and for any period of time readily to change over from a controlled to an uncontrolled supply, and vice versa, the consumption during periods in which the load control is made inoperative being charged at a higher price. The price change can be effected by a gear-change device in the kwh. register or in the prepayment mechanism of the meter, actuated in conjunction with the changeover in the operation of the load control. The necessary modification of apparatus and the extra cost entailed are both of a minor nature.

\section{Siting of Power Stations}

A Paper by F: Favell (J. Inst. Elec. Eng., 89, Pt. 2 , No. 9 ; June 1942), on the considerations to be given to this subject, points out that in recent years the siting of electricity-generating stations has tended to be affected increasingly by non-technical considerations such as legal requirements, amenities, etc. These considerations become of special importance when a particular scheme is submitted to a public inquiry by the Electricity Commissioners under Section II of the Electricity (Supply) Act, 1919. The paper records some of the issues to be borne in mind when siting power stations in Great Britain and at the same time it refers to some factors which have a bearing on power station construction irrespective of location. It is divided into two main parts, the first dealing with considerations arising out of parliamentary legislation, and the second with more technical and practical problems. The first part refers to the Town and Country Planning Act, 1932; the Coal Act, 1938 ; the Coal Mines Act, 1930 ; and various other statutory requirements. The second part deals with chimney emissions; sewage effluent for circulating water; amenities ; and alternative sites.

\section{Californian Fisheries}

THE report on the commercial fish catches of California for the year 1940 (State of California Department of Natural Resources. Division of Fish and Game. Bureau of Marine Fisheries. Fish Bulletin No. 58 ; 1942) makes available the summaries of commercial fish landings in each region of the State and also includes tables of numbers and nationality of the commereial fishermen and the number of boats of each type engaged in the fishery. A rapid development of the shark fishery is outstanding and is caused by the high price offered for liver oils of high vitamin A potency. This increase in the shark fishery, with 